\title{
THE EFFECT OF EXPOSURE FACTORS ON RADIOGRAPHIC IMAGE QUALITY ON THORAX PHANTOM WITH PA PROJECTION
}

\author{
*Aryadiva Nugrahaning Prayoga', Nanik Suraningsih¹, Mega Indah Puspita1 \\ 'Widya Husada Semarang University \\ *divaprayoga988@gmail.com¹, naniksuraningsih78@gmail.com², megaindahpuspitaa@gmail.com³
}

Submitted : 12 Desember 2021. Accepted : 26 Januari 2022. Published : 28 Januari 2022

\begin{abstract}
The posteroanterior projection (PA) chest radiograph is the most frequently performed radiological examination for various purposes of diagnosis. Radiographic examination of the anatomy of the body can provide as much information as possible which can be determined by the Radiologist, which requires good quality radiographic images. To be able to produce radiographs that provide as much information as possible, optimal radiographs are needed. In the radiographic examination, factors that can affect the quality of the photo are needed in order to get good results. These factors include the exposure factor. Exposure factor consists of mains voltage (kV), tube current $(\mathrm{mA})$ and time $(\mathrm{s})$.

The objectives to be achieved in this study were to determine the effect of exposure factors on the quality of radiographic images on the use of phantom thorax with PA assessment. The method used in experimental research. This research was conducted at the Laboratory of the Diploma III X-Ray Engineering Study Program, Widya Husada University, Semarang. In several variations of exposure factors, there is no difference in quality both in terms of sharpness and sharpness. The resulting image from each variation is good and informative. So it can be useful that the use of exposure factors is chosen as minimal so that the exposure or dose received is smaller. Image quality analysis should be made with a wider variety of $\mathrm{kV}$ and $\mathrm{mAs}$, and using phantom objects other than phantom thorax.
\end{abstract}

Keywords: Exposure Factors, Image Quality, Thorax

\section{BACKGROUND}

Radiographic examination of the anatomy of the body can provide as much information as possible which is easily determined by a radiologists, requiring good quality radiographic images. Radiographic quality is very influential in determining the accuracy of the diagnosis of a disease in the radiodiagnostic field (Dhahryan and Azam, 2009). Minister of Health Regulation No. 1014 of 2008, that one of the services at the Radiology Installation is radiodiagnostic services, namely services for making diagnoses using ionizing radiation, including conventional $X$-rays, Computed Tomography $\mathrm{Scan} / \mathrm{CT}$, and mammography. One of the examinations using conventional X-ray is a chest x-ray examination. X-ray examination aims to diagnose abnormalities found in the lungs and surrounding organs. Thoracic radiography examination technique is a photo shoot using a tube voltage that is high enough to show an image of the organs and bones in the thorax (Sari, 2018).

To be able to produce radiographs that provide as much information as possible, optimal radiographs are needed. In the radiographic examination, factors that can affect the quality of the photo are needed in order to get good results. These factors include the exposure factor. Exposure factor consists of mains voltage $(\mathrm{kV})$, tube current $(\mathrm{mA})$ and time (s). Electrical voltage $(\mathrm{kV})$ is a unit of potential difference between the cathode and anode in the Roentgen tube. $\mathrm{kV}$ or electric voltage will determine the quality of x-rays and the penetrating power of $x$-rays, the higher the amount of electrical voltage used, the greater the penetrating power (Bushong, 2020). In determining the mains voltage, it is better to use an optimal voltage that is able to produce clear object details. Things that affect tube voltage are: type of shooting, thickness of object, shooting distance, equipment used (Padang, 2010).

One of the efforts in image quality assurance is Quality Control (QC) procedures related to the supervision and maintenance of radiodiagnostic equipment. All these tests are regulated in the Ministry of Health of the Republic of Indonesia No. 1250/MENKES/SK/XII/2009 concerning Guidelines for Quality Control of Radiodiagnostic Equipment. Quality Control is a quality assurance program for equipment that is carried out regularly with the aim that the equipment 
is always in good condition to produce maximum output. The quality and safety of radiodiagnostic services is the most important factor because it can pose a danger to staff, patients and the surrounding environment if not managed properly, so it is necessary to carry out quality control regularly. One of the Quality Controls that becomes important in diagnosis is the quality of the resulting radiographic image. Radiographic quality is a determinant of the diagnosis of a disease. Utilization of radiation sources requires the acceptance of the lowest possible dose to patients, radiation workers and the public. Radiological examination is expected to be able to obtain quality radiographs with minimal radiation exposure. Radiographic quality is the ability of radiographs to provide clear information about the object or organ to be examined. Radiographic quality is determined by several components, including: density, contrast, sharpness and detail. Exposure factors are factors that affect and determine the quality and quantity of $\mathrm{X}$-ray radiation required in making radiographic images. The exposure factor consists of tube voltage $(\mathrm{kV})$, tube current $(\mathrm{mA})$, and exposure time (ms) (Pradana, 2011).

Based on the above background, the researcher is interested in adopting it as a research and studying more deeply about "The Effect of Exposure Factors on Radiographic Image Quality on Thorax Phantom with PA Projection". This study aims to see the effect of exposure factors on the quality of radiographic images on the use of phantom thorax with PA and projections to obtain a chest radiographic examination protocol that is able to provide the best image quality.

\section{METHOD}

This research is an experimental research, namely research that is directed to determine the effect of exposure factors on the quality of radiographic images on the use of Phantom Thorax with PA projection. The phantom is exposed using variations of $\mathrm{kV} 55$ and $\mathrm{mAs} 10$ and 12, and $\mathrm{kV} 60$ and $\mathrm{mAs} 10$ and 12. Then processing the film using CR so that the image can be assessed. Data analysis uses a visual grading system by applying an image quality assessment based on eye observations. Then choose the best radiographic result and then measure the image visualization parameters and the gray degree histogram. The analysis is carried out on the contrast (Contrast) and sharpness of the image (Sharpness). Sharpness is the ability to show a clear boundary between two areas that have different densities (Nurhidayah, 2017). In the gray level histogram analysis, information will be obtained about the distribution of the gray level intensity of the image based on the gray level distribution using the Java Image-J Basics version 1.38 software platform.

\section{RESULT AND DISCUSSION}

This research was conducted to determine the effect and the optimum value of the exposure factor from a radiographic image by using histogram indicators to see the degree of gray in a radiographic image. Presented research data in the form of radiographic images of Phantom Thoraks at the Laboratory of the Diploma III X-Ray Engineering Study Program, Widya Husada University Semarang, which was conducted in April 2021. Exposure was carried out with variations in tube voltage and current using an X-ray mobile aircraft with the Toshiba Rotanode E7252X aircraft brand.

In this study, the effect of exposure factors on the quality of the radiographic image on the use of Phantom Thorax with PA projection is to evaluate the resulting image. The variation given for each voltage and current is done to limit the number of doses received with the existing image quality. Changes in X-ray tube voltage affect the gray level of the resulting radiographic image. The higher the voltage used, the lower the gray level produced (Muttaqin and Susilo, 2017). For this reason, it is necessary to have variations of kV: 55, mAs: 10 and 12 and kV: 60, mAs: 10 and 12 on the PA Thorax projection. Then the resulting image is measured based on the image visualization parameters and the gray degree histogram. The analysis was carried out on the contrast and sharpness of the image using a visual grading system by applying an image quality assessment based on eye observations. Then choose the best radiographic result. In the gray level histogram analysis, information will be obtained about the distribution of the gray level intensity of the image based on the gray level distribution using the Java Image-J Basics version 1.38 software platform.

Exposure factor is an internal factor that controls the characteristics of X-ray photons in terms of quantity (quantity) and (quality) and duration in making radiographs. To determine the large influence of the exposure factor on image quality, it is necessary to vary the value of tube voltage $(\mathrm{kV})$ and a fixed current value ( $\mathrm{mAs})$. Taking chest $\mathrm{X}$-rays with variations of $\mathrm{kV}: 55$, mAs: 10 and 12 and kV: 60, mAs: 10 and 12 on the PA Thoracic projection. The value of this Exposure Factor condition is the examination condition for the PA thorax (rays pointing from back to front). 
Tabel 1 Variation of Voltage on thorax PA Radiography Image Results

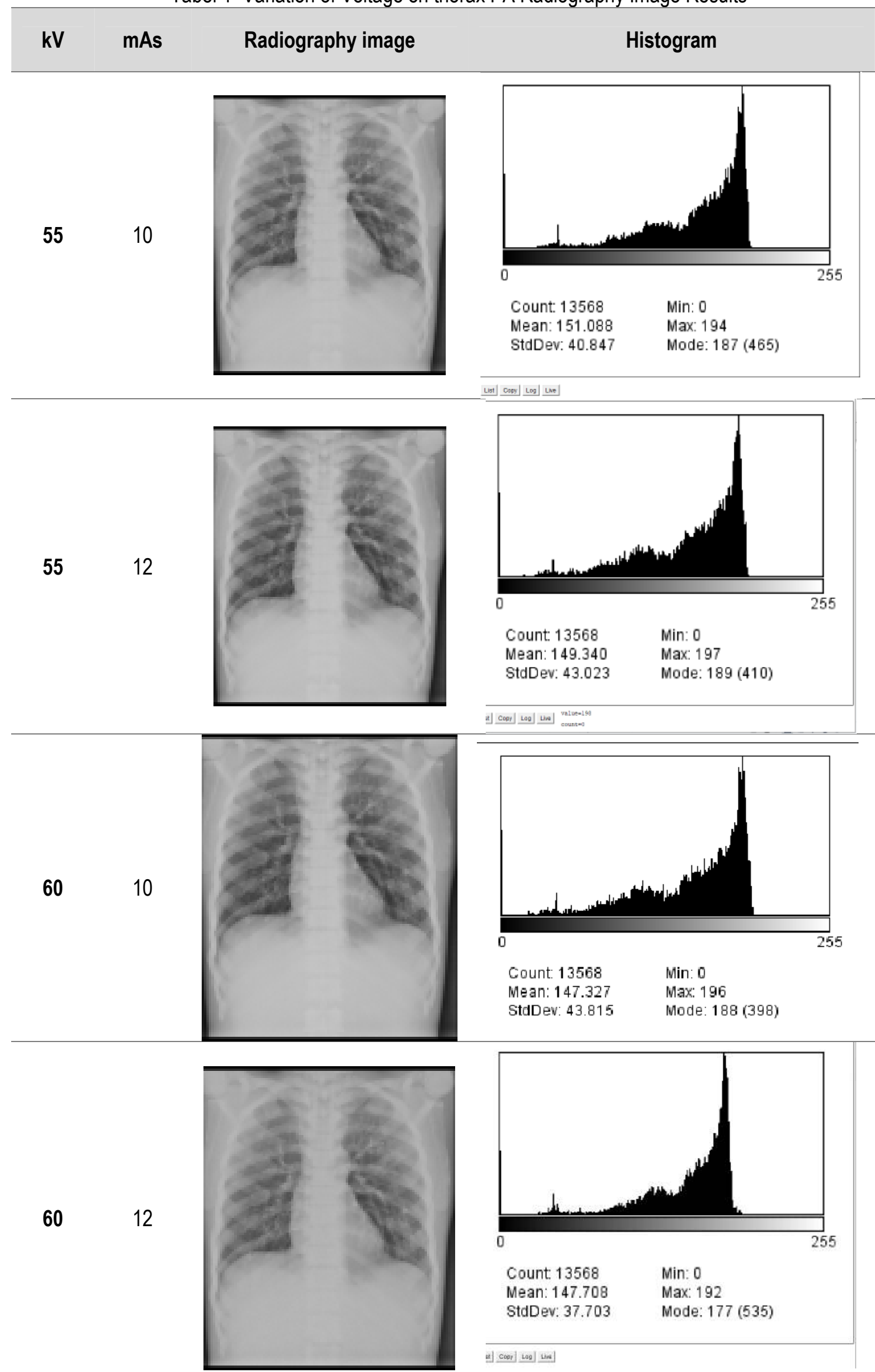

Image quality analysis is carried out based on image visualization parameters which include contrast and 
sharpness of the image and analysis of the gray degree histogram to obtain information about the distribution of the gray level intensity of the image based on the gray level distribution using the Java Image-J platform software with the size of the radiographic image obtained, namely $106 \times 128$ pixels and 8-bit resolution.

Based on the results of visual grading and measurement results using histogram diagrams on the Image $J$ application, several variations in exposure factors did not find any difference in quality in terms of contrast or sharpness. The resulting image from each variation is good and informative. So it can be concluded that the use of exposure factors is chosen as minimal so that the exposure or dose received is smaller.

Histogram is a graph that depicts the distribution of pixel intensity values, namely the brightness and contrast of an image. The peak histogram shows the intensity of the prominent pixels, the width of the peak shows the contrast range of the image. Based on the histogram graph, it can be seen that the image is dark or light, if the dominant histogram graph occupies a minimum area then the image is a dark image, but if the dominant histogram graph occupies the maximum area then the image is a bright image. A good image is if the histogram graph fills the gray scale area completely with an even distribution at each pixel intensity. Table 1 shows the histogram graph for each voltage variation where all the resulting images have histogram graphs that are not evenly distributed at each intensity. The pixel intensity is not distributed so that the resulting radiographic image is still an imperfect image category. Based on histogram analysis, the tube voltage used should use a minimum voltage and current of $55 \mathrm{kV}$ and $10 \mathrm{mAs}$ because the histogram graph produced on the radiographic image is not much different from variations in other exposure factors and the radiation exposure received by the patient

Based on eye observation or visual grading, the image quality produced by all variations, both $\mathrm{kV}: 55, \mathrm{mAs}: 10$ and 12 and kV: 60 , mAs: 10 and 12, has no significant difference. The image is able to produce good contrast and sharpness. The overall image quality is also good and able to show a clear anatomical picture. So that for the selection of the exposure factor itself on Thorax examination with PA projection, it is possible to use the lowest voltage and current, thus it is considered to be able to reduce the radiation dose received by the patients.

\section{CONCLUSION AND SUGGESTION}

Exposure factor is an internal factor that controls the characteristics of $\mathrm{X}$-ray photons in terms of quantity (quantity) and (quality) and duration in making radiographs. To determine the large influence of the exposure factor on image quality, it is necessary to vary the value of tube voltage $(\mathrm{kV})$ and a fixed current value (mAs).

In several variations of exposure factors, no differences in quality were found, both in terms of contrast and sharpness. The resulting image from each variation is good and informative. So it can be concluded that the use of exposure factors is chosen as minimal so that the exposure or dose received is smaller.

Image quality analysis should be made with more diverse $\mathrm{kV}$ and $\mathrm{mAs}$, and using phantom objects other than Thorax phantom.

\section{REFERENCE}

Bontrager K. (2020) . Texbook of Radiographic Positioning and Related Anatomy Seventh Edition.

Bushong, S. C. (2020). Radiologic Science for Technologist : Physics, Biology, and Protection

Dhahryan. dan M. Azam. (2009). Pengaruh Teknik Tegangan Tinggi Entrasce Skin Exposure (ESE) dan Laju Paparan Radiasi Hambur Pada Pemeriksaan Abdomen. Jurnal Berkala Fisika. ISSN:1410-9662 Vol. 12, No. 1.

Kepmenkes RI. Keputusan Menteri Kesehatan Republik Indonesia Nomor 1014/Menkes/Sk/Xi/2008 Tentang Standar Pelayanan Radiologi Diagnostik Di Sarana Pelayanan Kesehatan. Jakarta 2008

Keputusan Menteri Kesehatan Republik Indonesia Nomor 1014/Menkes/Sk/Xi/2008 Tentang Standar Pelayanan Radiologi Diagnostik Di Sarana Pelayanan Kesehatan

Lampignano, John P. Kendrick, Leslie E. (2018). Bontrager Textbook of Positioning and Related Anatomy,Fifth Edition. CV. Mosby Comapany. St. Louis.

Long, B.W, Rollins, J.H, Smith, B.J. (2016). Merril of Atlas Radiographic Positioning and Radiologic Procedures, therteen Edition Vol. II. Missouri : Mosby, Inc.

Mutaqqin, R. Dan Susilo. 2012. Uji Banding Kualitas Citra Radiograf Sitem Radiografi Digitak Modifikasi Terhadap Computed Radiogrphy System dengan Metode Contrass to Noise Ratio. Physics Communucation. Semarang. ISSN:2528-5971. Vol 1, No1. 
Nurhidayah, Nehru, Eif S. (2017). Pengaruh Faktor Eksposi Terhadap Kualitas Citra Radiografi. JoP, Vol. 3 N0. 1, November 2017: 14 -22

Padang, O. P.-U. B., ( 2010), undefined. (n.d.). Fisika Radiasi.

Pearce, Evelyn C (2016). Anatomi dan Fisiologis Untuk Para Medis, Cetakan kedua puluh Sembilan. Jakarta: PT. Gramedia Pustaka Utama.

Pradana A. E. D., (2011), Pengukuran Penggunaan kV Pada Pemeriksaan Thorak Anak Terhadap Kualitas Gambar Dan Dosis Radiasi, Universitas Indonesia FMIPA, Jakarta.

Sari, A. W., \& Fransiska, E. (2018). Pengaruh Faktor Eksposi dengan Ketebalan Objek pada Pemeriksaan Foto Thorax Terhadap Gambaran Radiografi. Journal of Health (JoH), 5(1), 17-21. https://doi.org/10.30590/vol5no1-p17-21

Sriwahyuni (2017). Pengaruh Tegangan Tabung (kV) terhadap Kualitas Citra Radiografi Pesawat $\begin{array}{llll}\text { Sinar-X Digital } & \text { Radiography } & \text { (DR) }\end{array}$ Phantom Abdomen. Jurnal Fisika dan Aplikasinya Volume 2 Nomor 2

Utami, A.P, Dewi A.M,Anisa N.I.(2020). Pengaruh Variasi Arus Tabung terhadap Kontras pada Pesawat Sinar-X High Generator. Jurnal Imejing Diagnostik (JImeD) 6 (2020) 11-15

Wibowo A.S, Gatot M.W, Anang P.(2016). Analisis Perubahan kV dan mAs terhadap Kualitas Gambar dan Dosis Radiasi pada Pemeriksaan Multislice Computed Tomography Abdomen dalam Kasus Tumor Abdomen Di Instalasi Radiologi RSUD Dr. Saiful Anwar Malang. Jurnal Imejing Diagnostik (JlmeD) Vol. 2 No.1. 